\title{
Moving in Silence and Violence: Some Thoughts on the Archaeology of Piracy
}

\section{Adam McKernan-Dawson}

University of Oxford: Institute of Archaeology, email: adam.mckernan.dawson@gmail.com

\begin{abstract}
From Thucydides' Archaeologia to Robert Louis Stevenson's Treasure Island, literary tales of swashbuckling pirates have long captured the imagination of the public. Despite this, attempts to produce an archaeology of piracy have largely been unsuccessful. This has led historians (and some archaeologists) to dismiss piracy as a phenomena that cannot be understood using archaeological methods, only historical ones. Yet, the last 10 years have seen an unprecedented spike in archaeological publications in piracy, notable examples including Persistent Piracy: Maritime Violence and State-Formation in Global Maritime Perspectives (Amirel \& Muller, 2014) and X Marks the Spot: An Archaeology of Piracy (Skowronek \& Ewan, 2007). So how has piracy transformed from a thema non grata in archaeology to one of the fastest developing subjects in maritime archaeology? Encompassing a series of periods, ranging from Ancient Cilicia to modern day Puntland, this paper will look at how changes in the social and academic perceptions of piracy have altered how we can perceive piracy from an archaeological perspective. Topics covered will include theoretical developments and social changes which have altered the perception of piracy. This paper will go on to review how these ideas have contributed to the creation of an archaeology of piracy characterised by seasonality, high quality goods in low socio-economic regions and a form of third party backing which allows piracy to function as a sub-group of organised crime.
\end{abstract}

\section{Key words}




\section{Introduction}

Maritime violence and maritime adventure have long captured the imagination of popular audiences. The excitement and danger found in seafaring is a key narrative component of stories spanning numerous genres and time periods The Homeric epic The Odyssey, one of the earliest surviving stories in western literature, focuses on the adventures of an intrepid sailor, travelling and fighting in foreign lands during his journey home from the Trojan War Similar themes are found in other ancient literature. The ancient Greek romance The Adventures of Leucippe and Clitophon (2nd Century AD) features the main characters being captured by Egyptian pirates (Ach. 5.7). More fancifully the Roman satire A True Story (2nd Century AD) has the author blown of course while sailing through the Pillars of Hercules which leads him to a series of exotic locations including the moon (Lucian 1). More recently, Johnson's A General History of Pyrates (1724) was immensely popular and led to the pirate archetype depicted in later publications such as Treasure Island (1883). In the modern day, the Disney film franchise Pirates of the Caribbean is one of the most successful film franchises of all (Nash Information Services, 2020). Given the long-lasting prominence, it is not surprising that pirates and piracy are some of the most readily recognised elements of modern pop culture. Given this extensive literary tradition, it is perhaps surprising that there is a relatively short tradition of studying piracy through archaeology. Piracy has traditionally been dubbed an "invisible culture" (Beek, 2015: 270) meaning that it cannot be seen in the archaeological record. This idea gained traction in the late 1990s, when early studies into the archaeology of ancient piracy yielded few results (Rauh, 1997: 2), which strengthened the position of ancient historians (de Souza, 2002: 2). Historians typically fail to cite any archaeological evidence when attempting to decolonise piracy, instead preferring to read "along the textual grain" (Rediker, 1980: 4; de Souza, 2002: 7). This is a conscious choice; there has traditionally been little to no success in integrating archaeology into pirate studies. Particularly damning are de Souza's (2002: 2) comments that ancient piracy is a textual-only phenomenon that cannot be understood through material remains. This is somewhat paradoxical as a large body of de Souza's evidence comes from epigraphy, which are not simply textual documents, as there is a great deal of importance related to the place of an inscription within the landscape. However, the development of new archaeological techniques and theories has allowed a rethink of our approach to pirate studies. This report will show how theoretical and social changes in the past two decades have altered our perception of piracy, and how these new developments can be used to build an archaeology of a previously invisible phenomenon. 


\section{The Politicisation of Piracy: A History of Pirate History}

A major issue with creating an archaeology for piracy is that the term "pirate" is, and always has been, politically loaded. This is evident even from the earliest mentions of piracy, which come from The Odyssey. While piracy is rarely described directly, it is used as a narrative device in the poem. Eumaeus's backstory recounts how he became a slave after being stolen and whisked away to sea by a woman who herself had been captured and sold by pirates (Od. 15. 415-436). Likewise, Odysseus, to explain his destitute situation in Book 14, concocts a fictious story about how a pirate attack on Egypt went awry, ruining him (Od. 14.257-265). In both instances the episodes serve as cautionary tales about the dangers of leading an immoral life. Characters engage in piracy out of greed or jealousy and end up destitute or enslaved as a result. In places, Odysseus undertakes actions which could be considered piratical, most notably his raid on the Cicones in Book 9. Instead of being condemned, the raid is praised, and after the Trojan War is one of the few high points for Odysseus and his crew (Od. 9.39-44). The message here is clear: Odysseus' actions are acceptable because he is a Greek noble. Were he a Cretan or Tyrrhenian, his actions would be barbaric and immoral. It is the inherent "goodness" and civilisation that Odysseus and his Greeks possess which prevent their being defined as pirates, not their actions. This is also reflected in Thucydides' "History of the Peloponnesian Wars". In the four books titled, Archaeology, Thucydides mentions how piracy was commonplace at the time of the Trojan wars because numerous petty kingdoms were constantly fighting, and no power had the strength to bring peace to the seas (Thuc 1.3-4). In fact, Thucydides mentions that the first major act of Minos, whom he considered the ruler of Greece's first major civilisation, was to attempt to clear the seas of piracy (Thuc. 1.4). In both instances the emergence of piracy reflected the chaos which originated from a lack of civilisation. Piracy as a concept is portrayed as the antithesis of progress.

In the Hellenistic period piracy evolves from a passive literary trope designed to show the absence of civilisation, to an active political tool utilised by states to exert their influence over the seas. The earliest mention of Cilician pirates comes from the geographer Strabo ( 1 st Century BC) (14.5.2) in his description of the region Cilicia. However, Cilician pirates are commonplace in the ancient histories, appearing in the works of almost all contemporary historians. The prevalence of Cilicians in Roman literature is more about what their defeat meant for Rome as a whole, as opposed to the severity of threat they posed. Cilicia's defeat built upon Rome's victory over Carthage in the west, cementing them as a major power in both the eastern and western Mediterranean. While the Ptolemies of Egypt remained a prominent sea power, it was with the defeat of Cilicians that the Mediterranean started to become Mare Nostrum for the Roman people. 
Modern academic interest in piracy began at the end of the 19th century with Sestier's La Piraterie Dans L'Antiquit (1880). His ideas were then expanded upon by the epigraphists Ormerod, writing in 1924 in English and Ziebarth writing in German in 1929 respectively. These three would lay the foundation for all future studies on ancient piracy. Many of the ideas about the Cilicians that are now taken as a fact, such as how their profit primarily derived from the slave trade, or that their emergence parallels the decline of the Seleucid empire, were conceived in this period (Ormerod, 1924: 201). Although not directly related, these writings were likely influenced by the fascination with The Golden Age of Piracy that was prevalent in Western society in the 19th a century a phenomenon that might be called pirate romanticism.). Notably, Sestier's opus was published just after the opening of the Pirates of Penzance (1879) and three years before Treasure Island (1883). This may go some way to explain the three's approach to ancient piracy. Ormerod, Sestier and Ziebarth are all guilty of treating piracy as a static, unchanging phenomenon. Notably, Ormerod (1924: 14) describes pirates found in Homer as "[P]ursuing a mode of life almost identical with that of Frankish corsairs" despite the fact "Homeric" piracy predated the Franks by well over 1000 years. While there are undoubtably similarities in tactics and settlement patterns, piracy was (and still is) a dynamic activity subject to the social, economic and technological changes. Making direct comparisons between Homeric piracy and Frankish raids may result in losing the nuances which made each instance unique. Furthermore, Ormerod's reliance on ancient sources causes him to unchallengingly replicate classical ideas towards piracy. This is particularly clear when he states that the main reason piracy flourished in the 1 st century BC was the lack of a strong naval presence in the Eastern Mediterranean (Ormerod, 1924: 199). This is an uncritical reassertion of the same argument offered by Strabo (geog. 14.5.2), writing in the 1 st century BC. This narrative supports the idea that piracy was a conflict between barbarity and civilisation, reinforcing the notion that piracy occurs as a result of moral failure.

\section{Theoretical Developments}

The concept of piracy described in the previous section can be classed as "Ciceronean" piracy. This term, coined by Gabrielsen (2013: 134), states that piracy is a direct result of moral failure. This term comes from Cicero's speech in de Officiis (3.29.107), in which he states that pirates lack the basic morality to be treated as humans and therefore should not be protected by the same laws as "civilised" people. The antithesis of this viewpoint is the "Augustinian" view of piracy. This term comes from a passage of St Augustine's "City of God". St Augustine describes a conversation between a captured pirate and Alexander the Great. When asked why he terrorises the seas, the pirate replies “... because I do it with a petty ship, I am called a robber, while you who does it with a great 
fleet are styled emperor" (Aug. City. 4.4). The crux of this concept is that piracy is a socio-political term utilised by states. The title of Chomsky's "Pirates and Emperors" comes from this exert, and his main thesis is similar, that national states monopolise "just war" and label any action they disagree with as terrorism (Chomsky, 2003). This allows states to both justify their own actions while at the same time denouncing those of their opponents. Understanding the difference between these two concepts is essential when trying to determine how archaeology can be applied to pirate studies.

It is easy to see why ancient sources and writers from the early 20 th century adhered to the Ciceronean theory of piracy. In both periods the writers were firmly entrenched in a colonial society that may have considered piracy as an "otherness" disruptive to their worldview. Furthermore, as Ormerod, Ziebarth, and Sestier all treated piracy as a static and uncomplicated phenomenon, it left little room for further research, resulting in pirate studies stalling throughout the 20 th century. It is perhaps telling that it is only with the development of post-colonialism that studies into piracy were reinvigorated. A pioneer of this post-colonial approach to piracy was American historian Markus Rediker, whose publication Between the Devil and the Deep Blue Sea (1987) was one of the first works which approached piracy by focusing on the social and economic factors that drove sailors to piracy. Subsequently, in the 1990s, the Augustinian method began to be used to study ancient piracy. Scholars such as Avidov (1997), de Souza (2002) and Rauh (2003) re-examined to what extent the Cilicians can be truly considered pirates. All three, to different extents, believe that the Cilicians cannot simply be labelled a nation of pirates. de Souza in Piracy in the Graeco-Roman world (2002), sticks to the epigraphic roots of Ormerod and Ziebarth. He posits that the Cilicians were not pirates in the modern sense of the word but were labelled so by Romans as it provided a casus belli to expand their influence over the Mediterranean. He further states that Rome's interest in supressing piracy was only superficial and that piracy was still prevalent throughout the Mediterranean after Pompey’s campaign (de Souza, 2002: 156). Avidov (1997), comes to a similar conclusion, but focuses more on economic analysis over epigraphy. He states that the Cilicians were retrospectively labelled pirates by Roman historians and that many of the claims made by these historians were economically unfeasible (Avidov, 1997: 24-29). Avidov instead suggests that the Cilicians represented an important naval power in an anti-Roman faction intent on challenging Rome's emerging supremacy in the Mediterranean. The recent publication of Lambert's (2018) "Seapower States" takes a similar approach as that of de Souza and Avidov. While he does not focus on piracy, a key part of his methodology involves understanding how maritime powers present themselves and how it differs from terrestrial empires. In all three instances, the authors' works differ from that of early writers as they attempt to understand smaller seapowers from the view of these seapowers. 
Another major development in the field of pirate studies was the emergence of the concept of "persistent piracy". This concept seeks to differentiate commonplace naval banditry from long term localised piracy. Introduced by Amirell \& Muller (2014: 1), persistent piracy differentiates singular actions of maritime violence and long-term piracy integral to the economic development of pseudostates. Persistent piracy is closer to modern day organised crime than the actions traditionally described in academia. It involves persistent, decentralised groups loosely affiliated by the shared aim of achieving wealth through maritime violence. What separates this from earlier ideas about piracy is that although groups are acting independently, they all receive some form of funding from a third party. This continuous investment allows piracy to thrive. The concept of persistent piracy allows piracy to be reconsidered as something more than a purely seaborne activity. It instead sees it as an inevitable consequence of social and economic inequality, turning it into a phenomenon that can be studied on land by analysing the host of support networks involved in it, which can subsequently be used to detect the material culture left by pirates.

\section{Social Developments}

The previous decade has also seen several changes within our society as a whole which have made the Augustinian method of approaching piracy much more appealing. Two events particularly in Western society are the failure of the War on Drugs and the exponential growth of piracy being practiced in the Gulf of Arden. Both these events have, in their own way, altered perceptions and approaches to the types of people who practiced piracy. The War on Drugs was a US campaign designed to limit the production and consumption of illegal narcotics within the USA. Although the term was first coined by Richard Nixon in 1971 (Barber, 2016), it was under the Reagan administration that the program was enforced in earnest. President Reagan increased the budget of the Drug Enforcement Agency (DEA) from US\$8 million to US\$95 million and introduced the "Comprehensive Criminal Control Act", which enforced strict federal penalties for the possession of recreational drugs (Pub. L. 98-473).

There are notable similarities between political attitudes of people within the drug industry and the treatment of pirates by hegemons. The War on Drugs considered drug dealing and drug taking a result of moral failure, where blame laid with the individual actors within the system. As a result, drug dealing, or production, could be used as a "State of Exception" by the USA to exercise extralegal authority over both foreign and domestic groups. Daghir (2016: 52) notes how after the beginning of Operation Just Cause in Panama, the US media was quick to tout the narrative of Manuel Noreiga as a vicious drug trafficker. This narrative superseded the less ethical aspects of Operation Just Cause, such as US interests in the Panama Canal, or the violation of international law 
as confirmed by the UN (United Nations, 1989: 173-4). Likewise, Alexander (2020) notes how the War on Drugs essentially replaced the Jim Crow segregation laws as a method of racial discrimination and oppression in US domestic policy. In both drug dealing and piracy, poor groups are given the opportunity to earn more money illegally than they ever could through legal means.

A review undertaken by the UN-backed Global Commission on Drug Policy declared the War on Drugs a failure and urgent policy changes were required (2011: 19). This had the effect of generating sympathy for actors in the drug industry, evident from the surge of literature on this topic, after the failure of the War on Drugs (Gootenbubrg, 2009; Rovner, 2009; Campos, 2012). In addition to this, scholars such as Campos (2012) focused on the long-term human cost the War on Drugs has had on individuals, generating increased interest in individuals previously marginalised or designated as “others”, such as pirates.

Another development in international relations which has allowed for the creation of new narratives on piracy is the failure of the state of Somalia and the subsequent spike in piracy in the Gulf of Arden. To narrate the near 200-year history of Somali piracy would be far beyond what is possible within the scope of this thesis. The most recent episodes, however, can be linked to 1991, when persistent civil wars, combined with drought, placed severe economic pressure on the people of Somalia. A myriad of factors, including unemployment, poverty, lack of foreign aid, illegal foreign fishing, and climate change led to piracy becoming common in the Gulf of Arden, largely based out of Puntland, an autonomous region which had broken away from Somalia (Ingiriis, 2009: 240). This is a well-documented case that has provided the opportunity to use Somali piracy as an ethnographic case study to better understand historical piracy.

Maritime ethnography, in an archaeological context, is the process of using modern day maritime societies as case studies to better understand similar societies in the past. It came to prominence in archaeology at the beginning of the new millennium with McGrail et al's (2003) Boats of South Asia, which used anthropological research on the Indian subcontinent to understand the developments of boat technology in South Asia. This book and the research of Blue (2002) led to the popularisation of maritime ethnography roughly five years before Somali piracy increased in frequency. The failure of the War on Drugs and the rise of Somali piracy may then be linked to the increased literature related to piracy (Amirel \& Muller, 2014; Skowronek, 2016; Gulseth, 2016) which became prevalent in the 2010s. This, in turn, created more interest and offered more depth to studying piracy than had been possible up until this point.

\section{Towards an Archaeology of Piracy}


Modern approaches to piracy show that groups within a state with limited infrastructure, that are excluded from participating in the boom in maritime trade during their eras, enter piracy as a way of benefitting from this wealth. This can be seen by looking at case studies from a range of periods such as Cilicia (Roman), Woodstown, Ireland (Viking), Ratcliff, England (Jacobin) and Hadaharee (modern day Somalia), all of which show evidence that piracy stimulates urban development for these groups in the same way that trade does for larger nations. In this way piracy could be considered a means to an end for smaller sea powers. Unable to compete with larger nations on economic scale, piracy provides an alternate opportunity to generate capital.

\section{Cilicia}

Nicholas Rauh is the archaeologist who has made the greatest contribution to the archaeology of Cilicia. Working with the Alanya museum, he directed the Rough Cilicia Survey Project (RCSP) from 1996 to 2011. The goal of this project was to evaluate urbanism and local assimilation within a $60 \mathrm{~km}$ strip of southern Turkey, the modern provinces of Alanya and Icel (Rauh, 1997: 1). While Rauh $(2003 ; 2009 ; 2013)$ demonstrates an active interest in Cilician piracy and acknowledges its important role in Cilician history, the scale and scope of the RCSP prevented intensive research into a single period. Nevertheless, Rauh's (2009: 273) theories about the origins of urbanisation in Cilicia are pivotal to re-considering the role of pirates within an economic system. During his survey of Rough Cilicia, Rauh discovered that there was large increase in imported Hellenistic fine-wares, starting between $150 \mathrm{BC}$ and $100 \mathrm{BC}$ (Rauh et al, 2009: 272). He posits that this increase indicates a large influx of wealth, which was a key factor in urban development (Rauh et al, 2009: 272). Rauh goes on to suggest that the cause for this boom was the riches collected through Cilician piracy. This is evident in a number of satellite settlements which surround later Roman cities (Rauh, 1998; 1999), challenging earlier theories that the Romans were largely responsible for Cilician urbanisation.

\section{Woodstown}

A common argument for the urbanisation Viking raid camps such as Dublin and Novgorod is that they functioned as slave markets and pit stops for travelling Norsemen, as well as entrepôts between Christian and Norse spheres (Wall, 2010: 48). Thus, the concentration of capital at Viking raid bases caused several of them to develop into towns. As urbanisation increased, and protection became less of a necessity, raiding settlements were often supplanted by ones more suitable for trade. For example, in Ireland, Woodstown was abandoned for the site of Waterford, a settlement on the same 
river, but closer to the coast (Wall, 2010: 41). It is likely these bases were based on proto-urban Scandinavian settlements as many of these features can also be seen in Viking Aarhus and Hedeby (Hilberg, 2008: 104; Sindbaek, 2008: 152). It is noticeable that at Woodstown, as urban artefacts such as market weights appear, defensive features such as the rampart became neglected, suggesting a transition from a military site to a more commercial settlement (Hurley \& Russel, 2014: 32).

\section{Ratcliff}

Likewise, the combination of documentary and archaeological evidence has been essential for identifying sites related to Jacobin piracy. A landmark investigation into this area was undertaken by Killock and Meddens (2005) who were analysing material discovered in 2000 during commercial excavations of 43-53 Narrow Street, Ratcliff, London. This area proved anomalous to archaeologists for, despite being firmly located in a lower socio-economic maritime area, there is a huge spike in imported fine ware pottery starting in the late 16th century and remaining consistently high throughout the 17th century (Killock \& Meddens, 2005: 19). This import level was not just higher than standard levels in Ratcliff, but significantly higher than the majority of Great Britain (Killock \& Meddens, 2005: 24). The lack of merchants active in the area and the absence of any identifiable grouping within the pottery assemblage made Killock and Meddens sceptical of the idea that these goods were acquired through trade (2005: 21). The development of Narrow Street from a riverside hamlet to the "one of the most prosperous areas of London" (Killock \& Meddens, 2005: 24) appears to be intrinsically tied to piracy in the 17 th and 18th century (Killock \& Meddens, 2005: 17). Starting at the end of the 16th century, Ratcliff became a hub for "Adventure Companies", founded by merchants unable to trade with the Spanish due to government embargoes, which would instead fund pirate ventures as an alternative way to make profit. However, by the time the embargo was cancelled it appears that the merchants were not interested in returning to trade, but instead saw the value of investing in piracy instead. This would turn out to be a highly lucrative endeavour and by the end of the 17 th century the financier of a pirate venture could make a return of investment of up to 400\% from a single expedition (Killock \& Meddens, 2005: 23). It would, therefore, appear that the influx of goods found in Narrow Street is linked to wealth brought into the neighbourhood via piracy. Imported property from colonial powers such as Spain, Portugal, and Italy was found in exceptionally high amounts when compared even to contemporary high-status sites (Killock \& Meddens, 2005: 17), possibly implying that they were seized from colonial ships. Supporting this is the appearance of significant amounts of Chinese white-and-blue ware, which was the favoured prize of pirates operating in the Indian Ocean (de Bry, 2008: 123). There is little to link these diverse types of wares, except that they all would have been traded in areas where pirates commonly operated. It is 
also highly unlikely that their original destination would have been London due to the low level of foreign imports into the city at this time. Killock \& Meddens (2005: 20) are keen to stress that this does not necessarily mean all the imported goods directly came from piracy, although a significant portion would have, but instead that the wealth brought in through piracy would have allowed the inhabitants of Narrow Street to trade in high value ceramics.

\section{Haradaheere}

A modern example of this form of urbanisation can be seen in Haradaheere in Puntland, often referred to as the "capital of the pirate stock exchange" (Moore, 2017). This small village allows locals to buy shares in pirate ventures that can be cashed in if the venture is successful (Moore, 2017). The efficacy of this exchange can be seen in a quote from a local of Haradaheere:

"[R] $[\mathrm{R}$ ardless of how the money is coming in, I can say it has started a life in our town. Our children are not worrying about food now, and they go to Islamic schools in the morning and play soccer in the afternoon. They are happy" (Hassan \& Kennedy, 2008). The value of stock exchange centres to the continuation of Somali piracy has also been noted by One Earth Future, where they note that the sophistication of Somali criminal networks allowed them to double the number of attacks within the Horn of Africa in between 2016 and 2017 (Pidgeon et al, 2017). As an investment centre specialising in piracy, Haradaheere can be seen as a modern incarnation of Ratcliff: both were poor socioeconomic areas which saw economic growth through pirate venture capital. Likewise, Viking chieftains would provide ships and manpower for raids and in return receive wealth and prestige.

Combining the documentary and archaeological evidence, it is possible to gain a further understanding of the nature of persistent piracy. Although pirate crews operated in an isolated fashion, it was still essential to have centralised areas for co-ordination and management of ships and crews. Furthermore, an increasingly recurring feature when looking at pirate sites is the evidence of non-uniform and multi-cultural material culture, which seems to reflect the indiscriminate nature of pirate attacks. Ratclilff, Woodstown, and Haradaheere all appear to have undergone an enormous increase in prosperity over a short period of no more than 50 years

\section{Conclusion}

While there is still no definitive solution for identifying pirate societies via archaeology, it is possible to see several recurring themes throughout several periods. Pirate settlements can best be described as anomalous. They show high levels of maritime connectivity and an abundance of high-status wares despite being in areas historically poor and isolated. Furthermore, this wealth appears to be gained in a relatively short period of time (no more than half a century). The evident link between 
piracy and urbanism shows that piracy was also closely linked to venture capitalism. It is the sustained investment from third parties which allows pirate crews to continuously partake in maritime violence. However, this does not mean we should consider these settlements "pirate cities". In fact, it appears that in all the aforementioned case studies, these urban centres are keen to distance themselves from piracy once they become significantly wealthy. While piracy may at first seem like an archaeologically invisible phenomenon, when we break down what piracy really consists of and how that is reflected in the locations used, it become possible to start building an archaeology. This report has only focused on three case studies; additional case studies might show that this trend is visible in numerous sites from many different periods. 


\section{Bibliography}

Alexander, M. (2020). The New Jim Crow. New York: The New Press.

Amirell, S., \& Muller, L. (2014). Introduction: Persistent Piracy in World History. In S. Amirell, \& L. Muller (Eds.), Persistent Piracy: Maritime Violence and State-Formation in Global Historical Perspectives (pp. 1-24). New York: Palgrave MacMillan.

Avidov, A. (1997). Were the Cilicians a nation of Pirates? Mediteranean Historical Review, 12(1), 555.

Barber. (2020, August 5). Public Enemy Number One: A Pragmatic Approach to America's Drug Problem. Retrieved from Richard Nixon Foundation: https://www.nixonfoundation.org/2016/06/26404/

Beek, A. (2015). Where Have all the Pirates Gone? . In F. Carrer, \& V. Gheller (Eds.), Invisible Cultures: Historical and Archaeological Perspectives (pp. 270-284). Newcastle Upon Tyne: Cambridge Scholars Publishing.

Blue, L. (2002). The Historical Context of the Construction of the Vattai Fishing Boat and Related Frame-First Vessels of Tamil Nadu and Beyond. In D. Parkin, \& R. Barnes (Eds.), Ships and Development of Maritime Technology on the Indian Ocean (pp. 278-290). London: Routledge.

Campos, I. (20212). Home Grown: Marijuana and the Origins of Mexico's War on Drugs. Chapel Hill: University of North Carolina Press.

Chomsky, N. (2003 ). Pirates and Emperors, Old and New: International Terrorism in the Real World. Boston (MA): South East Press.

Comprehensive Crime Control Act of 1984 (Pub. L. 98-473). (1984).

Daghrir, W. (2016). The Media and Operation Just Cause in Panama. Journal of Arts and Humanities, 5(5), 51-56.

de Bry, J. (2006). Christopher Condents Fiery Dragon: Investigating an early Eighteenth-Century Pirate Shipwreck off the coast of Madagascar. In Skowronek, \& Ewen (Eds.), X Marks the Spot: The Archaeology of Piracy. Gainesville: University Press of Florida.

de Souza, P. (2002). Piracy in the Greco-Roman World. Cambridge: Cambridge University Press.

Gabrielsen, V. (2013). Warfare, Statehood and Piracy in Ancient History. In N. Jaspert, \& S. Kolditz (Eds.), Seeraub Im Mittelmeerraum (pp. 133-153). Paderborn: Ferdinand Schoningh.

Gootneberg, P. (2009). Andean Cocaine: The Making of a Global Drug. Chapel Hill (NC): University North Carolina Press.

Gulseth, C. (2016). Black Bart's Ranger. In C. Ewen, \& R. Skowronek, Pieces of Eight: More Archaeology of Piracy (pp. 93-109). Gainesville (FL): Florida University Press.

Hilberg, V. (2008). Hedeby: an outline of its reasearch history. In S. Brink, \& N. Price (Eds.), The Viking World (pp. 101-111). London \& New York: Routledge. 
Hurley, F., \& Russel, I. (2014). Introduction. In I. Russel, \& F. Hurley (Eds.), Woodstown: A VikingAge settlement in Co. Waterford. Dublin: Four Courts Press.

Ingiriis, M. (2013). The History of Somali Piracy: From Classical Piracy to Contemporary Piracy, c. 1801-2011. The Northern Mariner/le marin du nord, 23(3), 239-266.

Johnson, C. (1724). A general history of pyrates, from their first time and settlement in the island of Providence, to the present time. With remarkable actions and adventures of the two female pyrates Mary Read and Anne Bonny. London: Printed for, and sold by T. Warner.

Killock, D., \& Meddens, F. (2005). Pottery as Plunder: a 17th Century Maritime Site in Limehouse London. Post-Medieval Archaeology, 39(1), 1-91.

Killock, D., \& Meddens, F. (2005). “Map of Ratcliff” Pottery as Plunder: a 17th Century Maritime Site in Limehouse London. Post-Medieval Archaeology, 39(1), 33

Lambert, A. (2018). Seapower States: Maritime Culture, Continental Empires, and the Conflict That Made the Modern World. New Haven (CT): Yale University Press.

McGrail, S., Blue, L., Kentley, E., \& Palmer, C. (2003). Boats of South Asia. London; New York: Routledge.

Moore, M. (2017). The Pirate Stock Market. Retrieved 02 11, 2020, from

https://psmag.com/news/the-pirate-stock-market-5935

Ormerod, H. (1924). Piracy in the Ancient World. Liverpool: JHU Press.

Pidgeon, M., Sadic, E., Duncan, S., Ridgway, C., \& Soeth, K. (2018). The State of Maritime Piracy 2017. Broomfield (CO): One Earth Future.

Rauh, K. (2003). Merchants, Sailors and Pirates in the Roman World. Cheltenham: Tempus.

Rauh, N. (1997). Rough Cilicia Archaeological Survey Report: Report of the 1997 Season. Rough Cilicia Archaeological Survey Report, 1-18.

Rauh, N., \& Wandsnider, L. (1999). Rough Cilicia Archaeological Survey Report: Report of the 1999 Season. Rough Cilicia Archaeological Survey Report, 1-11.

Rauh, N., Dillon, M., \& Rothaus, R. (2013). Anchors, Amphoras and Ashlar Masonry: new evidence for the Cilician Pirates. In Hoff, \& Townsend (Eds.), Rough Cilicia: New Historical and Archaeological Approaches. Oxford and Oakville: Oxbow Books.

Rauh, N., Townsend, R., Hoff, M., Dillan, M., \& Doyle, M. (2009). Life in the Truck Lane: Urban Development in Western Rough Cilicia. Jahreshefte des Österreichischen Archäologischen Institutes in Wien, 78, 253-313.

Rediker, M. (1989). Between the Devil and the Deep Blue Sea: Merchant Seamen, Pirates and the Anglo-American Maritime World, 1700-1750. Cambridge : Cambridge University Press.

Rovener, E. (2009). The Cuban Connection: Drug Trafficking, Smuggling, and Gambling in Cuba from the 1920s to the Revolution. (R. Davidson, Trans.) Chapel Hill (NC): University North Carolina Press.

Sestier, J. (1880). La Piraterie dans l'antiquite . Paris. 
Sikora, M. 2020. "Scale reconstruction of Viking Dublin" The City of Dublin. National Museum of Ireland. https://www.vikingeskibsmuseet.dk/en/professions/education/viking-knowledge/theviking-age-geography/the-vikings-in-the-west/ireland/the-city-of-dublin (accessed 01/06/2020)

Sindbaek, S. (2008). Local and Long-distance exchange. In S. Brink, \& N. Price (Eds.), The Viking Exchange (pp. 140-158). London \& New York: Routledge.

Skowronek, R. (2016). Setting a Course Towards an Archaeology of Piracy. In C. Ewan, \& R. Skowronek, Pieces of Eight: More Archaeology of Piracy (pp. 1-14). Gainesville (FL): University Press Florida.

Stevenson, R. L. (1923). Treasure Island. London: Cassell and Company.

United Nations. (1989). Yearbook of the United Nations Volume 43 (Vol. 43). New York:

Department of Public Information.

Wall, R. (2010). Woodstown and Urbanisation: Interpretations, Models and Questions. The Journal of the American Society of Irish Medieval Studies, 4, 26-52.

Ziebarth, E. (1929). Beitrage zur Geschichte des Seeraubs und Seehandels im alten Griechenland. Hamburg.

\section{Ancient Sources}

Achilles Tatius

The Adventures of Leucippe and Clitophon Translated by Gaselee, S. (1969)

Augustus of Hippo

City of God. Translated by Bettenson, H. (1972)

4.4

Cicero

Off. Translated by Miller, W. (1913)

3.29.107

Homer

Odyssey. Translated by Rieu, E. (2003)

9.39-44

$14.257-265$

$15.415-436$

Lucian

A True Story Translated by Harmon, A. (1913)

Strabo

Geography. Translated by Jones, H. (1924) 


\subsection{2}

Thucydides

Translated by Crawley, R. (2009)

$1.3-4$ 